\title{
FROM KERAJAAN (KINGDOM) TO KERAJAAN (GOVERNMENT)
}

\author{
Koh Chien Aun \\ Sivachandralingam Sundara Raja
}

\begin{abstract}
Although research has been done on Malaysia's history textbooks, much of it focuses on the Malay/non-Malay dichotomy and the imbalances between the two. And while there is much in agreement of a Malay hegemony in the history narrative, little is said about the Malay thought present within the textbooks as a standalone. This paper aims to cover a portion of this Malay thought, specifically that of the kerajaan narrative through a discourse analysis of the secondary school History textbooks. The analysis shows a largely superficial veneration of the sultans in contrast to the reverence afforded to them within the boundaries of Malayness. Instead, a modern Malay nation-state is emphasised with the kerajaan serving as; 1) a means to validate an already present pre-colonial Malay civilisation; 2) to frame and redefine certain concepts within the confines of the nation-state; and 3) efforts to downplay Western influences within Malaysia, despite the textbooks inability to fully detach from the former. This discourse analysis provides a further nuance to the understanding of our History education and Malay identity, beyond mere dominance of one ethnic narrative over others. By exploring the discourse of the kerajaan present within the textbooks, this paper aims to contribute towards the body of research that explores the continual engagement between Malayness and an ever changing world today.
\end{abstract}

\section{Introduction}

In Benedict Anderson's seminal work entitled Imagined Communities, he notes that the modern nation-state is imagined political community. ${ }^{l}$ In the case of post-colonial states such as Malaysia, an integral facilitator of this imagined community is the spread of a modern education system that is initially promoted by the colonial state. ${ }^{2}$ Post-independence, the structures of these education system are still present despite a potential change in trajectory towards a more 'localised' context. As such, Malaysia's secondary school History textbooks can thus be seen as instruments whereby the Malaysian nation-state and Malayness/Malaysian-ness are explicitly and implicitly reproduced and imagined by Malaysians through a predetermined period of their education. ${ }^{3}$ This paper aims to explore one aspect of History education, the Malay royal institution, and thus its (re)imagining within the Malay/Malaysian public as explored within the Malaysian secondary school textbooks through a discourse analysis.

Although not constitutionally defined as integral to Malayness, the Malay royal institution has always been seen as an important nodal point, a lynchpin of Malayness within Malaysia. For it is within the institution by which all three traditional pillars of Malayness are encapsulated - Raja, Islam, and Adat. Prior to the Malay Peninsula's colonialization by Western powers, this institution was at its political height in the form of the kerajaan system ${ }^{4}$ or Malay kingdom/sultanate from which the ruler was its heart. Such extent was the ruler's centrality in providing purpose and meaning for communities in that point of time, that it was thought better to be under the patronage of a ruler than to own land ${ }^{5}$. Today, the kerajaan system has largely been replaced by a constitutional monarchy, whose head of state, the Yang di-Pertuan Agong, ${ }^{6}$ retains some of the institution's previous power. Legally, the Federal Constitution recognises the Yang di-Pertuan Agong as head of the religion of Islam and certain provisions afford him absolute discretion: 
40. (2) The Yang di-Pertuan Agong may act in his discretion in the performance of the following functions, that is to say:

(a) the appointment of a Prime Minister;

(b) the withholding of consent to a request for the dissolution of Parliament;

(c) the requisition of a meeting of the Conference of Rulers concerned solely with the privileges, position, honours and dignities of Their Royal Highnesses, and any action at such a meeting, and in any other case mentioned in this Constitution. ${ }^{7}$

Likewise, the sultans of Malaysia's various states are afforded similar provisions within their respective states. Take for example Article 55 (2) of the Constitution of Selangor:

(2) His Highness may act in His discretion in the performance of the following functions (in addition to those in the performance of which He may act in His discretion under the Federal Constitution) that is to say:

(a) the appointment of a Mentri Besar;

(b) the withholding of consent to a request for the dissolution of the Legislative Assembly. ${ }^{8}$

Despite having such limited powers currently when compared to the sultans of the past, it is still very clear that they hold a functional role within Malaysia as an institution. Additionally, the inclusion of "Loyalty to King and Country" as part of the National Principles, to the local practice of petition the Yang di-Pertuan Agong and evocative cries of "Daulat Tuanku" by various Non-Government Organisations from the breadth of the Malaysian political spectrum; are suggestive of the institution's currency and resilience 9 . Thus while much has changed through the course of time, it would be erroneous to conclude that the vestiges of the kerajaan system as irrelevant within contemporary Malaysia.

\section{The Kerajaan in Malaysia's History Textbooks (1989-current)}

The Malay kerajaan system is a prominent feature within the Malaysia History syllabi, making over to two fifths of the total content. A large bulk of this is within the early secondary level textbooks (Form 1 and 2). The Form 1 texts covers the rise and fall of the early Malay kerajaans, with special attention given to the Malaccan-Johorean kerajaan. Although an initial content analysis of the textbooks showed a great number of sultans named, few of these rulers' reigns are fleshed out in detail in the current textbooks. Of these mentioned, most of the Malaccan sultans were under a small section entitled "The Leaders' [Malacca] Ingenuity" which recounted positively some of their exploits. ${ }^{10}$ Sultan Muzaffar Shah was seen as "acting wise"; Sultan Alauddin Riayat Shah was "pious" and "strong"11. In contrast and partly due to a slight difference in the textbooks' narrative structure of the 1990s series, the 1990s Form 1 textbook provides a more detailed coverage of some sultans and their exploits but in a more neutral tone. Meanwhile, the Form 2 text of the same series details to great extent the gradual colonisation of the Malay kerajaans by the British in the $19^{\text {th }}$ Century. Both syllabi highlight the failings and infighting between the royal courts as one of the key factors in the involvement and eventual colonisation by the British. Nevertheless, the late $19^{\text {th }}$ Century Johor kingdom is viewed positively in the Form 2 texts.

Considering the prominence of the sultans within the kerajaan ideology, it is noteworthy that they do not feature as extensively as individuals within the textbooks as expected. Instead, more generalised explanations are given on their functionary roles as absolute monarchs. Both syllabi highlight too the sultans' ties to Islam and their integral role in the spreading of Islam within the region through their conversions, marriage, and 
encouragement of Islamic evangelism ${ }^{12}$. Moreover the mentioning of a sultan's name usually serves as a chronological timestamp of certain important historical developments occurring during the highlighted period and Malay sultanate ${ }^{13}$. Surprisingly, the current series affords the sultans greater privilege. ${ }^{14}$ The current Form 1 textbook, for example, extols "loyalty towards the King" as a moral value that the readers should follow as shown by various individuals and groups towards their sultans. ${ }^{15}$ Such moral judgements are absent from the 1990s series. Bendahara Tun Perak is referenced as an exemplary figure of this point, the textbooks citing the Sejarah Melayu ${ }^{16}$ as their source:

This was shown [his loyalty to the king] when Bendahara Tun Perak did not seek revenge when his son Tun Besar was killed by the prince, Raja Muhammad. Bendahara Tun Perak only asked that Sultan Mansor Shah did not elect Raja Muhammad as his heir. ${ }^{17}$

Thus, he is credited as being greatly loyal to Sultan Mansor Shah by not committing treason in the murder of the sultan's heir. In contrast to this, the textbooks lament the British interferences within the Malay Archipelago, considering these as "threatening the sultan's daulat" and "challenging the sultan's eminence". 18

\section{Creating Proto-national Myths for Malaysia}

But what is central focus of the narrative despite a great portion of the History syllabi being dedicated towards the exploration of the Malay kerajaans, if not the sultans? The answer to this question is oddly the kerajaans themselves as uniquely Malay institutions, ones which encompasses a larger Malay people beyond the sultans. There is a common theme in the textbooks in their establishing of a pan-Malay consciousness, thus the textbooks framing of the kerajaan system is further crystallization of this. The current textbooks frame these kerajaans as categorically Malay, as the following chapter titles from both Form 1 textbooks suggest; "Kerajaan Negeri-Negeri Melayu"; "Kerajaaan-kerajaan Melayu Tua" and "Kerajaan-kerajaan Melayu Baru". ${ }^{19}$ Whereas, it is unclear to what extent these kerajaans viewed themselves as explicitly Malay, the textbooks gives an impression of a pan-Malay identity at least among the various peninsular sultanates. ${ }^{20}$

Further evidence of this can be seen in the textbooks' highlighting of the importance the ruler's relationship with his people. The current Form 5 textbook notes that it is the ruler's responsibility to ensure his rakyat's safety, and thus in return, they pledge their fealty towards him a la a Hobbesian social contract. While this is true, Milner recognises that this could possibly be a relatively recent interpretation of kerajaan literature, one which should be contextualised with the waning relevancy of the kerajaan system with each successive translation. ${ }^{21}$ In addition to this, the kerajaan literature from that period were found to be focused on the sultans and their courts more so than the general welfare of his subjects. Nonetheless, as the sultan is no longer the primary focus of these kerajaans, there undoubtedly needs to be an ideological shift in how these kerajaans are representative of a greater 'Malay' people beyond the ruler.

The answer to this shift lies within the textbooks framing of the Malay kerajaans from a more contemporary lens. One that draws upon the conceptual underpinnings of a nationstate which it then imposes over the kerajaan system in as an identifiable form of popular proto nation-state. ${ }^{22}$ This is done in two ways; through content and through language, that is to say the reinterpretation of key nodal points (words/terms) in its dissemination of the subject matter. 
In order to reduce the amount of confusion and to provide clarity of the textbooks, the language used in the textbooks shall be explored first. In a subsection of Chapter 3 entitled 'Malay Malaccan Sultanate - The Foundation of Country and Citizenship' of the current Form 5 textbook, the authors tell the readers that "[the] characteristics of the Malay Malaccan Sultanate has many similarities with those of the modern nation-state today". ${ }^{23}$ This is an interesting appeal considering the definition and concepts for most of these characteristics represented here by single Malay words ${ }^{24}$ - are contextually different, apart from the shared sign (word); which the textbook confusingly admits. Most notably among these are the words kerajaan, kedaulatan, and rakyat which are conceptualised in the current Form 5 textbook as such:

Kerajaan represents the body that has been given power to administrate, watch the peace, to defend the country's kedaulatan and to establish diplomatic ties with other polities. In the pass, kerajaan only existed when there is a king. During the era of the Malay Malaccan Sultanate, the king or sultan was the highest authority with the help of the Bendahara, Penghulu Nedahari, Temenggung and Laksamana. They were the pillars of the ruling kerajaan institution and were given portfolios according to their tasks... 25

The rakyat are all inhabitants in a territory and they are bound by laws and rules enforced in said territory. During the era of the Malay Malaccan Sultanate, the rakyat had a responsibility to be loyal to the king that ruled. As a sign of loyalty, the rakyat were ready to defend the country... ${ }^{26}$

Kedaulatan is the highest power upon the citizen of a territory and this power cannot be limited by any party. Kedaulatan also refers to the power that is held by the state or ruler. The State or ruler can use any power they possess to draft and enforce laws. This means the State has absolute rights over its citizens. Kedaulatan ensures a country is free from meddling, coercion, domination or conquest of foreign powers. The meaning of kedaulatan in the Malay Sultanate is different from the modern country. During the era of the Malay Malaccan Sultanate, kedaulatan referred to the ruling king. The ruling king represented the negeri or his area of influence. ${ }^{27}$

A brief digression here into the historical and political context of these words will prove useful in appreciating the implications of the claims made by the textbooks.

Here in the Form 5 textbook, the Malay word kerajaan is noted as taking new conceptual meaning of 'government' due to colonisation ${ }^{28}$. However, the original meaning kerajaan is best translated by the English word 'kingdom'. Much like how the 'king' within 'kingdom' connotes the centrality of a monarch within the polity, the raja in kerajaan suggest an identical standing and perhaps even the conceptual foundation. There are nonetheless differences in how the historical kerajaan saw itself from its western counterparts. It was firstly geographically fluid; in that there were no fix geographical boundaries of where one kerajaan begin and the other ended. Milner notes of previous observations of Malay 
rulers sometimes admitting to having no clue of the exact dimensions of the realm they govern over ${ }^{29}$. This is due to the fluid nature of the people ${ }^{30}$ of the Malay Archipelago and the regions' attitude towards land ownership ${ }^{31}$. Within the textbooks, the term is used frequently and it can be assumed that the context varies accordingly to the form of 'polity' 32 that is being talked about.

The word kedaulatan in the kerajaan (kingdom) has no direct translation and it is perhaps best describe as a supernatural power which serves as a sign of his divinely kingship. The daulat is reflective of the term's Hindu origins which grants the monarch "an aura of sanctity or sacredness as well as bestowed on him temporal authority" much alike the ancient Chinese emperors' heavenly mandate ${ }^{33}$. The arrival of Islam and the conversion of many of these monarchs changed little politically. Where he was once a divine being, he was now divinely appointed by God. Regardless, the implications was straightforward; the subjects had to serve with complete and unquestioning loyalty. As Omar notes: "Loyalty entailed submission and acceptance of a hierarchical social system which placed the common Malay firmly on the lowest rung of the social scale." 34 The textbooks make no clear connection of these Hindu origins, opting instead to deem the daulat as the Sultan's sovereignty by virtue of equating it as similar to state sovereignty: "The king that ruled represented the negeri or area of his control" 35 . Though subtle, this is noteworthy - either as an erroneous fact or intentional revision - as the daulat historically carried a very different connotation:

To be specific, just because those who may once have exercised sovereignty, or aspired to do so, were characterized by the sacred cosmic daulat that they were believed to embody and emanate does not entail that daulat means - that it is identifiable as or coterminous with - what we, in a different universe of meaning, call "sovereignty. ${ }^{36}$

As sovereignty is better understood as derived from the daulat vis-a-vis sovereignty is an equivalent to daulat.

The rakyat were thus the ruler's subjects which were made up of the peasantry and craftsman that sought the patronage of the monarchs. Part of the source of the kerajaan's (kingdom) dynamisms, they were highly mobile, moving from one sultanate to another which competed amongst each other. In those days, labour was currency: "Rulers celebrated a gain in subjects and bemoaned their loss. ...In the literature of the royal courts, a great ruler was one to who, many people owed allegiance". ${ }^{37}$ This symbiotic relationship between monarch and subjects governed the expectations and interactions of the pre-colonial Malay Archipelago. However, the equivalent of the rakyat according to textbook is now that of people ${ }^{38}$ bounded specifically by territory.

The textbooks treatment of the word negeri too, is different from its early usage. Here, negeri is seen as having fixed geographical boundaries of various sizes as determined by the British Colonial period through various treaties that is translatable to the English word 'state'. As the current Form 5 textbook points out:

For the tradition Malay community, negeri meant 'region', for example negeri Larut, negeri Bernam, and negeri Krian. In agreements between the Malay kerajaan [kingdom] and foreign powers, the entirety of the kerajaan [kingdom] is called a negeri along with its conquests. Thus when the British interfered in the Malay Peninsula, the British referred to each 
Malay kerajaan [kingdom] as negeri. The British set the boundaries of each kerajaan [kingdom]. The kerajaan system is archaic and has been replaced by the concept of negeri. ${ }^{39}$

Here we see again a shift from the kerajaan system towards western ideas of statehood. There is a significant implication here, though it might be lost on the textbooks targeted readers. Like many of these Malay words highlighted, negeri as 'state' denotes an entirely different meaning from its pre-colonial usage. Various anthropologist and ethnographers have pinpointed negeri to often be no larger than settlements - often defined by rivers - whereby a ruler is present or rules from. ${ }^{40}$ A kerajaan (kingdom) could thus have many negeris or territories, of which their substance, the rakyat, held greater importance ${ }^{41}$. Negeri as state differs by placing political power within geographical boundaries. This is to say, that the land on which the sultan or rakyat stands on, places him/her within a negeri's jurisdiction. Furthermore and perhaps more importantly, it limits greatly the kerajaan's powers within geographical confines while simultaneously disassociating power as emanating from the ruler. Where the kerajaan (kingdom) was once able to grow as long as the rakyat pledge fealty, the negeri as state clearly defines where a sultan's daulat ends and encroaches upon another. This equally applies to the rakyat as noted above.

Whereas kedaulatan was tied exclusively to, and emanated from the ruler, it is now reinterpreted to refer to the sovereignty of the nation-state by which the rulers/sultans are now subservient by de jure. The kerajaan or as it has now been reinterpreted to mean that the government, is thus the current safeguard of the daulat and are seen to be the contemporaries of previous royal administrators in so far as they are the physical representatives of the sovereign - as an entity. As a result, the textbook seems to suggest that the state is to be respected and obeyed either as the direct representative of the sultan or perhaps even above him as these statements suggests: "This means the state has absolute rights over its citizens" and "In the pass, kerajaan (a polity) only existed when there was a king"42. Similarly, the rakyat has also taken on new meaning whereby the rakyat are no longer mere subjects but citizens bound not to the sultan but to the nation-state. Furthermore, in contrast to the relative mobility of the rakyat prior to colonisation, the rakyat are now accordingly defined by geopolitical boundaries of the Malaysian nation-state and her respective negeris. However, to what extent these concepts are translatable to the entire syllabus varies, considering that different authors were employed for the other forms with terms like daulat and bangsa ${ }^{43}$ proving to be vague at best. It must also be remembered that the main readers of these texts ranges from the ages of 13-17 and thus, their grasp of these terms beyond their more contemporary and common meanings are severely limited.

In terms of content, consider the textbooks' framing of the various peninsular kerajaan systems prior to colonisation as negeris which are often in the context of 'states', whose territorial boundaries are envisioned along those set by the British colonial rule. This is an important deviation from the traditional kerajaan system ideology because it distinguishes the ruler from his kingdom as separable entities, and as such, mutually exclusive. A salient example of this can be seen in the Form 5 textbook's explanation of the prerequisites of the Terengganu ministers, among others, as having "pledged loyalty to the sultan and kerajaan". "44 Likewise, the Malaccan kerajaan's success is attributed to the ministers' responsibly "upholding and defending the kedaulatan of the sultan and kerajaan Malacca". ${ }^{45}$ Thus one could now talk about the kerajaan system without necessarily giving central attention to the ruler, and this is true in the textbooks. ${ }^{46}$

Such a formulation by the textbooks additionally implies the importance of a larger community of people, and even, social fields beyond the royal courts. Indeed, as shown by 
Chapter 2, this group called the 'traditional Malay', are framed as a race or ethnicity (bangsa), rather than mere subjects of a ruler. The Form 1 texts cover the social-cultural aspects of the Malay community; instructing the readers to treasure these Malay cultural traditions and to "defend these identities of bangsa (race?)". ${ }^{47}$

Having distinguish the ruler from the negeri, the textbooks are now free to explore other aspects of the kerajaan deem to be important to the narrative; aspects which reflect conceptions of the modern state. One of these features within the Malay negeris is their written laws and constitutions. Cited examples of these are the Malaccan Hukum Kanun and Undang-undang Laut (Sea Laws); Johore's 1985 constitution; and Terengganu's Ittiqanilmuk bi-ta'dil il-suluk ${ }^{48}$. The current form 5 textbook explains that these constitutions serve to protect both the sultan and his state's sovereignty:

Beside this, the written constitution [of Terengganu] also shows the wisdom of the Terengganu ruler in increasing the efficiency of the government system and as a barrier or backbone in maintaining Terengganu's kedaulatan [sovereignty]. ${ }^{49}$

In the case of Johor:

The legislating of the written constitution is spurred by the Johor's ruler in building a democratic kerajaan [government] to replace the absolute monarchy. The declaration of the Undang-undang Tubuh Kerajaan Johor succeeded in strengthening Johor's administrative system and foiled the British's plan to control negeri [state of] Johor. ${ }^{50}$

The textbooks explains that these various written laws practiced by the sultanates can be seen as predecessors to the present day constitution on both federal and state levels:

One of the foundation blocks of country and citizenship is the primacy of laws in governance. The enforcement of laws is a formal to control the community based on the rules that have been gazetted. Laws are created to keep the peace and protect the people. The primacy of laws determines the structure of government, judiciary, language, religion and citizenship accepted by the community. ${ }^{51}$

Despite the acknowledgement of the sultan's role in the implementation of these laws, his purview in doing so is secondary to the narrative. Furthermore, some of these laws in turn, restrict the absolute powers enjoyed by the sultan. Note also in the case of Johor, the mentioning of democracy and the change from an absolute monarchy; a stark contrast to the early secondary textbooks lamenting of the lost/degrading of the sultan's daulat by the British.

Another aspect of the kerajaan system that is look at favourably by the textbooks is the use of ministers, whether be it the Bendahara or Laksamana of Malacca; or the $19^{\text {th }}$ century ministerial cabinets of Johor, Kelantan and Terengganu. Within the Form 5 text, Kelantan is singled out for its implementation of a Cabinet of Ministers in the $19^{\text {th }}$ century which "proves that Kelantan had a complex administrative system". 52 Malacca is likewise praised for its 'Sistem Pembesar Empat Lipatan' ${ }^{53}$ whereby the pembesar-pembesar 
(dignitaries) are seen as "pillars of the kerajaan institution" that guaranteed the tranquillity of the monarchy and kerajaan in Malacca". ${ }^{54}$ In the exploration of Johor in the early $20^{\text {th }}$ century, the textbook credits the Johorean dignitaries' cooperation with the sultan as an important factor in delaying Johor's colonisation by modernising Johor ${ }^{55}$. It is only with the loss of a key minister, Dato' Abdul Rahman Andak, did Johor fell into British hands according to the textbook.

This extends to the descriptors the authors use in qualifying these Malay kerajaan leaders whereby efficiency and systematic bureaucracy is commended; qualifiers more akin to an ideal modern nation-state. The Malaccan sultanate itself is describe positively several times as having "systematic rule", with generally "fair", "wise" and "efficient" rulers and administrators in economic activities such as trade and taxation. "Likewise the Johor, Terengganu and Kelantan sultanates were describe as "efficient" and "capable in their rule" in similar areas. ${ }^{57}$ Further elements that are applauded can be found in the chapter entitled 'Malacca's Glory'. Here, the current Form 1 textbook provides the reader with a number of other reasons through sub-topics: mature foreign relations; a trading and intellectual hub; and a regional empire. ${ }^{58}$ Other examples including the use of currency; the importance of education; economics; and its own unique culture are all highlighted throughout both series. Most of these are again all translatable towards ideas of a successful modern nation state.

Due to the above, it can be concluded that the textbook writers were either ignorant of the historical differences of the kerajaans they explored or were unconcerned (the more likely of the two); thus providing an ideological narrative which on one hand acknowledges and affirms Malaysia's Malay past, and yet embraces her more recent changes that makes her a modern nation-state. This seems to serve the purpose of laying the groundwork for a panMalay identity - from a peninsular perspective - on which the core identity of the Malaysian nation-state is built upon. These elements of both the kerajaan system and nation-state are ultimately realised in the Form 5 texts which explains the country's current political system and thus, the final evolution of the kerajaan institution in what can be a seen as the middle ground of these ideologies:

One important and unique trait of Malaysia is her constitutional monarchy. A constitutional monarchy means it is a monarchy led system based upon the Malaysian Constitution. The Yang di-Pertuan Agong acts according to the Malaysian Constitution and the Prime Minister's advice. In carrying out his duties, His Majesty cannot act on his own accept in certain areas... ${ }^{59}$

It is clearly evident here that the absolute monarchy, a key feature of the kerajaan system ideology of the past Malay polities, is no longer an ideal means of governance and despite the early lamentations by the textbooks on the loss of their daulat. And yet, they are kept relevant in a system that privileges the nation-state as ideological symbols of an older pan-Malay past.

Such juxtaposing of the kerajaan system ideology alongside that of the modern nation-state is undoubtedly problematic especially considering the latter's association with the British colonisation or the 'West'. As evident above, the textbooks firstly try to skirt this problem by layering over or identifying different aspects of the Malay kerajaan as forerunners of the modern Malaysian nation-state. Negeri Sembilan, for example, is attributed with practicing elements of democracy prior to the arrival of the British and as providing an early form of federalism that pre-dates the Federated Malay States. ${ }^{60}$ The Malaccan-Johorean sultanate has a special position in particular, being labelled "the foundation of our country and bangsa"61 as shown previously. 
In addition to this, modernity itself is seen as a means to ensure the sovereignty of the nation-state as the late Johor sultanate exemplifies:

The close relations Johor has with the British succeeded in maintaining kedaulatannya [Johor's sovereignty] till 1914. The ingenuity of her ruler and the introduction of a modern bureaucratic system succeeded in providing stability and economic prosperity. ${ }^{62}$

In this sub chapter, the readers learn of the leaders of Johor and their 'ingenuity' and 'brilliance' in developing and modernising Johor which gave the British "no excuse in interfering." ${ }^{63}$ Equally the readers are told that in Pahang, Sultan Ahamd "followed the actions of Sultan Abu Bakar in developing Pahang in order to stifle British expansion ${ }^{64}$. The textbooks gives an impression that these efforts in modernisation and administrative prowess as purely indigenous in nature, and a natural evolution of the kerajaan system; as a means to prevent colonisation and independent from contact with the British. ${ }^{65}$

Indeed, the Malay word for 'building' (membangunkan) and 'modernising' (memodenkan $)^{66}$ and their equivalents are not used when in the context of the British. This can be seen in the textbooks chapters and sections dealing with the British's economic endeavours within the Malay states. The current textbooks often frames these as 'exploitation' (mengeskploit), 'to grab' (membolot) or 'to profit' (mengaut) in a negative sense. ${ }^{67}$ Contrast for example the following passages describing similar efforts by the Sultan Abu Bakar:

Sultan Abu Bakar has modernised Johor's administration by having courts, post offices and a Works Ministry. In order to take care of the welfare of his rakyat (subjects/people?) he built schools, hospitals and roads. In order to guarantee Johor's peace, a police and military force was established. ${ }^{68}$

And the British:

The building of roads is only focused between areas that have economic importance to the British and is for the purpose of easing their rule over the Malay Peninsula. ${ }^{69}$

The British did not actually wish to advance education among the Malay children. Education is given in order the Malay might become better farmers and fishermen than their parents. Malay secondary schools were not prepared for the Malays to further their education. Malay school graduates are only qualified to be teachers, policemen, and to hold low positions within the kerajaan department. ${ }^{70}$

This strong antagonism to the British is oddly not transferred to the Japanese's occupation in World War Two. While the textbooks are critical of the British eroding the daulat of the sultan, similar criticism is not levelled at the Japanese despite the significantly more severe effect they had on the kerajaan system: 
In contrast with the pre-war British practice of having a dual form of government, that of direct and indirect rule, the Japanese governed Malaya as a single integrated colony under one supreme government headed by the MMA [Japanese Malayan Military Association] in Singapore. In so doing, the Japanese reduced the status of the Malay Sultans to that of minor officials, heads of the Islamic bureau, in contrast to their position under the British when they enjoyed the prestige of being, at least nominally, heads of their own states. ${ }^{71}$

Even this was only temporary, as instructions from Tokyo called for the removal of all the occupied states' sultans in July $1942 .{ }^{72}$ Although the textbooks do mention some of these events, they seem to gloss over them as largely inconsequential to the narrative. Overall the textbooks' tone of the Japanese occupation is less critical than that of the British. On one hand, they make note of the cruelty and the deception of the Japanese in promising independence, and on the other, it is viewed positively at times:

The Japanese's success in defeating the Western powers in World War 2 [early on] gave confidence to Asians to free their countries from colonisation. The Japanese fanned the spirit of nationalism among the inhabitants of the Malay Peninsula, Sarawak and Sabah. ${ }^{73}$

The opportunity to hold higher positions like this were never given during the British administration. Through this policy, the Japanese gave the opportunity to the Malays to hold high positions in the administration. ${ }^{74}$

Here we see again the denouncement of the British, and in the second excerpt, the greater value the textbooks place on more contemporary ideas of administration over those of the kerajaan system. Thus the textbooks interestingly substitutes the British with other foreign nations, in the case above, Japan.

In many ways, the current series resembles its predecessor in the 1990s. Certainly much of the content of the 1990s series has made its way into the current series. Similar to the current series are the definitions provided, albeit the lack of links being explicitly drawn between the modern nation-state and the Malay sultanates. Equally identical is the sultan's recognition as being vital in these polities as explained in the Form 5 texts, ${ }^{75}$ although the emphasis is very much structured around the various sultanates as functioning Malay polities; especially the Malaccan-Johor linked sultanates. Ultimately the series paints a comprehensive overview of life within the Malay sultanates and its 'traditional' Malay people within the peninsula as this is structured around a single chapter entitled 'The Legacy of the Malay Sultanates' ${ }^{76}$ This also meant that it is more Malay focused in its perspective, with stronger focus on the historical heritage of the past which it uses to solidify an understanding and pride in a very Malay oriented nation-state despite foreign influences:

The Malay Malaccan Sultanate has contributed greatly towards the governing system and culture in building our civilised 
nation. This civility is unique regardless whether its roots are from our motherland or from foreign influence. ${ }^{77}$

This contrasts the current series organisation which covers similar subject matter under title of 'The Awareness of Nation and People Building, ${ }^{78}$ which includes elaborations on the concept of the nation-state, country and citizenship. Thus while the 1990s series' authors explore the Malay Sultanates as a legacy or history, this differs to the authors of the current series explicit framing and linking of the Malay Sultanates directly under the conceptual framework of nation-state building. This is not to say that the 1990s series is any less guilty of viewing the kerajaan system from a nation-state lens. Much like the current series, its exploration of sultanates takes on the form of negeris rather than the kerajaans systems. Similar too are the matrices of success for these sultanates which mirrors the ideology of nation-state, though the link is less explicit.

It must be noted however, that the 1990s series' coverage of Western foreign influences and contributions is also more forthcoming and in-depth. While the textbooks do make note of the inequalities and hardships faced during the British rule, ${ }^{79}$ they also make note of the positive effects of colonial rule. Compare for example these excerpt on education with the current series mentioned previously:

When the British with other Malay states, starting with Perak in 1874 , they built more Malay schools. Once again the reports at that time showed that the Malay parents' response was cold. To overcome this problem, the British held studies on the Quran in the evening. ... The Malay dignitaries were asked to encourage Malay parents to send their kids to school. ${ }^{80}$

The condition of the Malay stream schools were not satisfactory not only from a education aspect but a developmental one. British colonial policies intentionally maintained Malays within their village life. The British government wanted to continue keeping Malays as padi farmers and fishermen except for a small section of the elite for administrators. $^{81}$

Here, the British efforts in getting the Malays into schools are mentioned along with their attempts to limit schooling for the Malays, creating a more holistic picture of British colonial rule as oppose to the current series. Additionally, benefits of urbanisation under the British are represented here to encompass all ethnic groups rather than just the Chinese or British which are caricaturised as city and town dwellers in the current texts. ${ }^{82}$ Thus, ideas of modernisation, regardless of origin is equally praiseworthy in the 1990s series unlike the current series. In a similar vein, local modernisation attempts such as those of the $19^{\text {th }}$ Century Johor Sultanate is celebrated. While Kedah is noted for its then Prime Minister, Wan Mat Saman Bin Wan Ismail, which made Kedah a "negeri [state] that is peaceful, prosperous and stable" 83 that Frank Swettenham acknowledged. ${ }^{84}$

\section{The Kerajaan and Malaysian Nation-building}

Based on the exploration of the textbooks' framing kerajaan, in all its forms, it is clear that there is an overlaying of one ideology over the other. Why such an amalgamation of 
ideologies occurs in the history textbooks is worth exploring. There are a number of coexisting factors worth considering, both prior to and contemporary to the time of the textbook's writing. The first of these is the social engineering of a "New Malay" by Dr. Mahathir, a seemingly ongoing project to make the Malays more competitive and independent amongst the so called races of Malaysia. To do so meant that the Malays would have to move beyond their feudal roots which he was critical of, and implied in his writings in both the Malay Dilemma and The Challenge:

Evidence shows that the rajas themselves were involved in business, although in the main what this amounted to was the appropriation of a certain portion of goods belonging to their subjects... In this ways amounts of clothing and jewellery were amassed by the rajas and the members of the courts. ${ }^{85}$

The Malay States became even more divided after the invasion of foreign powers far and near. There was always a monarch who was prepared to help a foreign power for personal gain. ${ }^{86}$

However, Mahathir was not an anti-royalist who wanted to do away with the sultans. As he initially identifies in his writings, the sultans "have in the past furnished and continue to present the Malay character", noting that by removing them "the last vestige of traditional Malaya would disappear". ${ }^{87}$ Thus he found is "it is essential therefore that the monarchy remains", or perhaps more accurately, what the royal institution it stood for within modern Malaysia as a reminder; the golden age of the Malay people prior to their colonisation. ${ }^{88}$ What required changing however, were the Malays' feudal mind sets and unquestionable loyalty to the various royal families which prevented them from adopting a more pan-Malay identity found within the concepts of nation-state:

It is clear from the history of the Malays that division and separation were part of the custom. Unity was not encouraged and was not customary. The Malays of the Peninsula and the Archipelago had a system that was based on fragmentation.

The solution to this according to Dr. Mahathir was thus one of urbanisation and development of the Malays at the expense of the 'Indians', 'Chinese', and even the royal institution should they interfere. ${ }^{89}$

Such personal ideological sentiments came into full light with the 1983 constitutional crisis, just prior to the printing of the 1990s series. The Mahathir Administration attempt to amend Article 66 of the Federal Constitution in order to curb the sultans' powers and limit their ability to interfere in legislation, was met with much protest and consternation by the royal houses and their supporters. ${ }^{90}$ The Mahathir Administration brought to bear the full brunt of the state's resources against the monarchy, setting up the confrontation as one between the rakyat (people) and the royalist. ${ }^{91}$ Ultimately a compromise but at great cost to the Agong's ability to prevent bills from becoming laws. Whereas the above shows the iron fist of the state through force, in some ways, the textbooks can be seen as a velvet alternative or softer power in shaping the discourse on the kerajaan. One which sees the royal institution as a reminder of the Malay past, whereby lessons for nation-building can be drawn from, but also subservient to the rule of law as a constitutional monarchy. The textbooks are merely 
attempting to perpetuate and disseminate this discursive hegemony on Malayness to its, generally Malay, readers. ${ }^{92}$

The Mahathir administration was also notably more hostile towards the British, perhaps a personal reflection of Mahathir himself considering the cordial enjoyed between the two countries prior to his prime ministership. If the royal institution were criticised by Dr. Mahathir, the British were outright vilified. Three months into his premiership he instituted the Buy British Last policy straining diplomatic ties between the two nation-states. In The Challenge, he deemed the 'West' as no longer deserving of its adulation especially among the Malays, which can "shape and control the Easter Mind to such an extent that it is ridden by an inferiority complex and guilt feelings." ${ }^{93}$ The contrasting views between the British and Japanese highlights the strong link of the Malaysian textbooks reflects this. Dr. Mahathir's, disdain for the British, and indeed the West in general, has led to Malaysia's 'Look East' policy; whereby lessons on statesmanship, modernisation and development were drawn from successful Asian countries such as Japan, South Korea and Taiwan. This would require some tact on the part of the Malaysian government in writing History considering her short occupation by the Japanese during World War II. As Cheah comments:

Consequently, for the purposes of strengthening its economic ties with Japan... the Malay-based Malaysian government has refused to play up Japan's wartime "bad-guy" role. It is content to forget. ${ }^{94}$

\section{Conclusion}

Pulling together the various elements of the kerajaan narrative together, a sense of the royal institution's place within contemporary Malayness is indicated. Firstly, its early forms as Malay kerajaan systems, provide a historical legitimacy for both a pan-Malay identity and Malay dominated nation-state. The former, through the categorisation of the peninsular sultanates as distinctively Malay; the latter through substitution of British influence by identifying of elements of the modern nation-state within these sultanates. Thus, the royal institution today serves mostly as a reminder of this long constructed, historical Malay narrative and legacy which demands due recognition. On the other hand, the textbooks positioning of royal institution as beneath the rule of law can be seen as a rethinking of the relationship between the monarchy and the people. One whereby ideas of feudalism, at least theoretically, are no longer relevant to the Malaysian nation-state and have been replace by a more people centric social contract - between government and citizen. Much like the copyists remarked by Milner, there is thus a revaluation of Malayness in the face of the contemporary context and shifts in political power.

From a language perspective, the exploration of the kerajaan narrative within the history textbooks is also enlightening discursively. The redefining or the adding on of new conceptual meaning to specific Malay words such as 'negeri', 'kerajaan', and 'kedaulatan' as show above have coloured the way readers engage the subject matter; in this case, from a nation-state orientation versus an exploration of the actual historical 'realities' of the kerajaan system. To be fair, this is not a new phenomenon present within the textbooks but rather an ongoing discursive practice, brought about by the region's drawing on Western concepts and continual engagement with its colonial past, despite its highly negative view of said influence superficially. Nonetheless it is an important point worth highlighting as the textbooks continue to serve as the general Malaysian's first and last substantial contact with Malaysia's history; thus, potentially shaping his understanding and treatment of various issues; in this case, in relation to one of Malaysia's oldest institutions. 


\section{Notes}

${ }^{1}$ Own emphasis. Benedict R. Anderson, Imagined Communities: Reflections on the Origin and Spread of Nationalism, New York: Verso, 2006, pp. 6-7.

${ }^{2}$ Ibid. p. 116.

${ }^{3} 5$ years minimum period less the student undergoes further studies in Form 6 or local matriculation courses.

${ }^{4}$ Kerajaan system - borrowing a term from Milner - is used here to denote 'kingdom' or 'sultanate' as oppose to kerajaan as government.

${ }_{6}^{5}$ Anthony Milner, The Malays, West Sussex: Wiley-Blackwell, 2011, p.60.

${ }^{6}$ A sultan from one of Malaysia's 13 states that has been elected by his peers through Malaysia's Conference of Rulers through rotation. The elected sultan holds office for 5 years before the position is passed on to the next appointee.

${ }^{7}$ Malaysian Constitution, art. 40. $\$ 2$.

${ }^{8}$ Selangor State Constitution, art. 55. §2. See Salehuddin Saidin, 'Understand the role of Rulers', The Star, 26 February 2013, last accessed 08/12/2015, http://www.malaysianbar.org.my/index2.php?option=com_content\&do_pdf=1\&id=36316 also for detailed explanations of these provisions.

${ }^{9}$ See 'Cries of 'Nazri resign' ring out at Istana Bkt Serene', Malaysiakini, 16 June 2015, accessed 08/12/2015, https://www.malaysiakini.com/news/302060.

${ }^{10}$ Ahmad Fawzi bin Mohd. Basri, Mohd. Do'ad bin Sakdan, \& Azami bin Man, Sejarah Tingkatan 1: Buku Teks, Kuala Lumpur: Dewan Bahasa dan Pustaka, 2012, p.82. See also Zainal Abiin bin Abdul Wahid, Khoo Kay Kim, Muhd. Yusuf bin Ibrahim, Nik Hassan Shuhaimi bin Nik Abdul Rahman, Mohd. Amin bin Hassan, Ahmad bin Adam, Mohd. Sarim bun Hj, Mustajab, D.S. Ranjit Singh, Ranjit Singh Malhi, \& Omar Farouk bin Syeikh Ahmad, Sejarah Tingkatan 1, Kuala Lumpur: Dewan Bahasa dan Pustaka, 1989, pp. 35-37.

${ }^{11}$ Ahmad Fwzi bin Mohd. Basri, et. al. Sejarah Tingkatan 1: Buku Teks, p.83.

${ }^{12}$ See ibid. pp.58, 74, 140; and Nik Hassan Shuhaimi et.al. 4: Buku Teks, pp.180, 196. There is a subtle distinction between this and the aforementioned ties between the sultans and Islam not explored here.

${ }^{13}$ Often found as the phrase "During the reign of..."

${ }^{14}$ Perhaps a result of a peculiar feature of the current syllabus, the Form 1-3 secondary textbooks seem to incorporate explicit moral lessons in their exploration of history from which individuals are highlighted for exemplifying such moral virtues. This moral value is also part of a moral syllabus akin to civic education which requires the students to memorise (36 values in all along with key words). See Kementerian Pendidikan Malaysia, KBSM: Sukatan Pelajaran Pendidikan Moral, Kuala Lumpur: Pusat Perkembangan Kurikulum, 2000, http://www.stsimon.edu.my/mn/wp-content/uploads/2015/05/Sukatan-Pelajaran-Pendidikan-Moral-KBSM.pdf, accessed 04/12/2015.

${ }^{15}$ See for examples Ahmad Fwzi bin Mohd. Basri, et. al. Sejarah Tingkatan 1: Buku Teks, pp. 52, 60, 84, 85 \& 102.

16 The Malay Annals.

${ }^{17}$ Ahmad Fwzi bin Mohd. Basri, et. al. Sejarah Tingkatan 1: Buku Teks, p.84.

${ }^{18}$ Ibid. p. 26 \& 47. See Nik Hassan Shuhaimi bin Nik Abdul Rahman, Muhd. Yusof bin Ibrahim Muhammad Bukhari bin Ahmad, and Rosnanaini binti Sulaiman, Sejarah Tingkatan 4: Buku Teks, Dewan Bahasa dan Pustaka, 2002, p.198; and Ramlah binti Adam, Shakila Parween binti Yacob, Abdul Hakim bin Samuri, Muslimin bin Fadzil, Sejarah Tingkatan 5: Buku Teks, Kuala Lumpur: Dewan Bahasa dan Pustaka, 2011, p.76 for definition of daulat and its uses within the textbooks.

${ }^{19}$ Ibid. pp.122-137; and Zainal Abiin bin Abdul Wahid, et. al., Sejarah Tingkatan 1, pp.43-53.

${ }^{20}$ See Anthony Milner, The Malays.

${ }^{21}$ See Anthony Milner, The Malays, p.90.

${ }^{22}$ To borrow a term used by Eric Hobsbawm as he tried to pinpoint factors leading to the rise of nation-states.

${ }^{23}$ Ramlah binti Adam, et. al. Sejarah Tingkatan 5: Buku Teks, p.75.

${ }^{24}$ It is in the Form 5 textbook that these words are conceptualised and its meaning differentiated clearly for the first time throughout the entire 5 year syllabus despite the usage of the frequent use of these words throughout the syllabus. The same seems to be true in the previous syllabus as well.

${ }^{25}$ Ramlah binti Adam, et. al. Sejarah Tingkatan 5: Buku Teks, p.78.

26 Ibid.

${ }^{27}$ Ibid., p.75.

${ }^{28}$ Ibid., p.65. 
${ }^{29}$ Anthony Milner, The Malays, p.58.

${ }^{30}$ Ethnographers and historians record how it was common for rulers to establish new centres only to move later on. See ibid pp.54-55.

${ }^{31}$ The Malay Archipelago rulers overall viewed land as less valuable than subjects. It was also often easy for someone to build and work on vacant land which was seen as unpossessed land rather than belonging to someone or a ruler. See Anthony Milner, The Malays, p.58.

${ }^{32}$ Perhaps a more apt substitute to the way kerajaan is used in the textbooks. The word kerajaan throughout this paper will be contextualised accordingly.

33 Ariffin Omar, Bangsa Melayu: Malay Concepts of Democracy and Community 1945-1950, (Kuala Lumpur: Oxford University Press, 1993), p.2.

${ }^{34}$ Ibid. p.3.

${ }^{35}$ Ramlah binti Adam, et. al. Sejarah Tingkatan 5: Buku Teks, p.76.

36 Clive Kessler, "Daulat, Kedaulatan, Sovereignty and Constituionalism", New Mandala, 2014 http://asiapacific.anu.edu.au/newmandala/2014/03/03/daulat-kedaulatan-sovereignty-and-constitutionalism/ accessed 10/11/2014.

37 Anthony Milner, The Malays, p.57.

${ }^{38}$ This is distinct from citizenship which the word bangsa seems to imply within the textbook.

${ }^{39}$ Ramlah binti Adam, et. al. Sejarah Tingkatan 5: Buku Teks, p.66.

${ }^{40}$ See for examples Di Sekitar Konsep Negeri, Wan Hashim Wan Teh \& Daniel Perret (eds.), (Kuala Lumpur: Kementerian Kebudayaan, Kesenian dan Pelancongan Malaysia, Ecole fracaise d'Extreme-Orient, Institut Alam dan Tamadun Melayu, Universiti Kebnagsaan Maalysia, 1999), pp.1-199; an anthology of works on the concept of negeri.

${ }^{41}$ See Anthony Milner, The Malays, pp.58-60.

${ }^{42}$ Ramlah binti Adam, et. al. Sejarah Tingkatan 5: Buku Teks, p.76.

${ }^{43}$ Bangsa is not explored in this paper.

${ }^{44}$ Own emphasis, Ramlah binti Adam, et. al. Sejarah Tingkatan 5: Buku Teks, p.85.

${ }^{45}$ Ahmad Fawzi bin Mohd. Basri et. al., Sejarah Tingkatan 1: Buku Teks, p.60.

46 This might not necessarily be a conscious endeavour.

${ }^{47}$ Ahmad Fawzi bin Mohd. Basri et. al., Sejarah Tingkatan 1: Buku Teks, p. 175.

${ }^{48}$ Ramlah binti Adam, et. al. Sejarah Tingkatan 5: Buku Teks pp.80-82,84-86.

${ }^{49}$ Ibid. p.86.

${ }^{50}$ Ibid. p. 82.

${ }^{51}$ Ibid. p.76.

52 Ibid. p.82.

${ }^{53}$ Literally 'Four Level Dignitary System'.

${ }^{54}$ Ramlah binti Adam, et. al. Sejarah Tingkatan 5: Buku Teks, p.78.

${ }^{55}$ Masariah binti Mispari, Johara binti Abdul Wahab, \& Ridzuan bin Hasan, Sejarah Tingkatan 2: Buku Teks, (Kuala Lumpur: Dewan Bahasa dan Pustaka, 2012), p.67.

56 'Systematic rule' See Ahmad Fawzi bin Mohd. Basri et. al., Sejarah Tingkatan 1: Buku Teks, pp. 58-60.

'Kebijaksanaan/bijak' (Wise) pp.52, 58, 60, 63, 64, 82, 84, \& 85. 'Kecekapan' (Efficient) pp.63 \& 83.

57 Ibid. pp. 108 \& 110; ${ }^{57}$ Masariah binti Mispari et.al., Sejarah Tingkatan 2: Buku Teks, p.63.

${ }^{58}$ See also Zainal Abiin bin Abdul Wahid et. al., Sejarah Tingkatan 1, pp.33-47 for similarities in the earlier series.

${ }^{59}$ Ramlah binti Adam, et. al. Sejarah Tingkatan 5: Buku Teks, p.167.

${ }^{60}$ Ibid. pp.87-88.

${ }^{61}$ Ibid. p.74.

${ }^{62}$ Masariah binti Mispari et.al. Sejarah Tingkatan 2: Buku Teks, p.63.

${ }^{63}$ Ibid. p.66-68.

${ }^{64}$ Ibid. p.42.

${ }^{65}$ By British I mean their endeavours either as an individual, company or nation-state.

${ }^{66}$ The one time 'memodenkan' is used in the British context, it is prequalified as negative with the word 'mengeksploit' or 'exploit'. See Masariah binti Mispari et.al. Sejarah Tingkatan 2: Buku Teks, p.145.

${ }^{67}$ See for example ibid. pp. $145 \& 158$.

${ }^{68}$ Ibid. p.65.

${ }^{69}$ Ibid. p. 147.

${ }^{70}$ Ibid. p.155. While a limitation was indeed set on Malay education, through the lack of context needs to be noted given the pervasiveness of Malay language schools today. A Malay could continue their education in an English secondary school although language would be an immense barrier. Furthermore, compulsory primary 
education was not mandatory until 1966. The average reader would have no knowledge of this, possibly leading to an overly exaggerated impression of British repression.

${ }^{71}$ Cheah Boon Kheng, Red Star Over Malaya: Resistance and Social Conflict during and after the Japanese Occupation, 1941-1946, (Singapore: NUS Press, 2003) pp.27-28.

72 Kobkua Suwannathat-Pian, 'British Colonial Rule, Japanese Occupation, and The Transformation of Malay Kingship: 1930s-1957', New Zealand Journal of Asian Studies, 11, 1 (June 2009), pp.106-131.See also Yoichi Itagaki, 'Some Aspects of the Japanese Policy towards Malaya under the Occupation, with Special Reference to Nationalism', in K. G. Tregonning, ed., Papers on Malayan History, Singapore: Journal of Southeast Asian History, 1962, pp.256-256.

${ }^{73}$ Ramlah binti Adam, Abdul Hakim bin Samuri, \& Muslimin bin Fadzil, Sejarah Tingkatan 3: Buku Teks, Kuala Lumpur: Dewan Bahasa dan Pustaka, 2012, p.29.

${ }^{74}$ Ibid. p.31.

${ }^{75}$ Siti Zuraina Abdul Majid, Muhammad Yusoff Hashim, Abdullah Zakaria Ghazali, Lee Kam Hing, Ahmad Fawzi Basri, \& Zainal Abidin Abdul Wahid, Sejarah Malaysia Tingkatan 5, Kuala Lumpur: Dewan Bahasa dan Pustaka, 1992, pp.24-26.

${ }^{76}$ Ibid. pp.23-54.

${ }^{77}$ Ibid. 53.

${ }^{78}$ In Malay 'Kesedaran Pembinaan Negara dan Bangsa'. The word 'Bangsa' has multiple meanings much like 'kerajaan' which can imply 'race' i.e. Malay, Chinese or Indian; or 'nation' i.e. German nation.

${ }^{79}$ Often seen in the more macro lens of Western Imperialism within South East Asia as a region.

${ }^{80}$ Zainal Abidin bin Abdul Wahid, Khoo Kay Kim, Muhd. Yusof bin Ibrahim, \& D.S. Ranjit Singh, Serajah Tingkatan 2, Kuala Lumpur: Dewan Bahasa dan Pustaka, 1989, p. 163.

${ }^{81}$ Ibid., p. 165.

${ }^{82}$ See Masariah binti Mispari et.al. Sejarah Tingkatan 2: Buku Teks, pp.123-159.

${ }^{83}$ Zainal Abidin bin Abdul Wahid et. al., Serajah Tingkatan 2, p.67.

${ }^{84}$ Ibid. p.68.

${ }^{85}$ Mahathir bin Muhammad, The Malay Dilemma, Singapore: Marhsall Cavendish Editions, 2008, p.50.

${ }^{86}$ Mahathir bin Muhammad, The Challenge, Selangor: Pelanduk Publications (M) Sdn, Bhd., 1997, p.155.

${ }^{87}$ Mahathir Muhammad, The Malay Dilemma, p.135.

${ }^{88}$ Ibid.

${ }^{89}$ Ibid. p.134. See also Barry Wain, Malaysian Maverick: Mahathir Mohamad in Turbulent Times, China: Palgrave Macmillian, 2009, pp.200-202.

${ }^{90}$ Khoo Boo Teik, Paradoxes of Mahathirism: An Intellectual Biography of Mahathir Mohamad, Singapore: Oxford University Press, 1995, pp.202-205; and Barry Wain, Malaysian Maverick, pp.203-206.

${ }^{91}$ Khoo Boo Teik, Paradoxes of Mahathirism, pp. 206-208.

${ }^{92}$ It is an attempt because this is by no means a complete project thus far, as contemporary Malayness is still fragmented although well-defined within the borders of Islam, Raja and Malay traditions.

${ }_{93}$ Mahathir bin Muhammad, The Challenge, p.51.

${ }^{94}$ Cheah Boon Kheng, Red Star Over Malaya, p.249. 